\title{
Peertechz
}
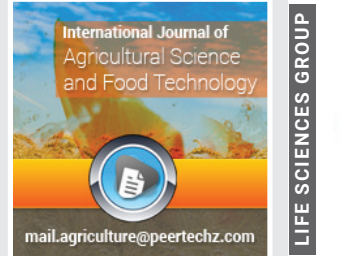

\section{Effect of different spacing}

on weed interference and

\section{performance of watermelon}

\section{(Citrullus Lanatus) in South Western Nigeria Rainforest}

\section{Zone}

\section{Adenubi $\mathbf{O O}$ and Sanni KO*}

Department of Crop Production and Horticulture, Lagos State Polytechnic, Ikorodu, Nigeria

Received: 24 August, 2020

Accepted: 05 September, 2020

Published: 07 September, 2020

*Corresponding author: Sanni KO, Department of Crop Production and Horticulture, Lagos State Polytechnic, Ikorodu, Nigeria, E-mail: sanni.k@mylaspotech.edu.ng, sannikehinde2002@gmail.com

Keywords: Optimum weed suppression; Thicker vines; Vine girth; Weed density; Weed interference

https://www.peertechz.com

\section{Check for updates}

\begin{abstract}
The spatial distribution of plants in a crop community is an important determinant of yields. An attempt was made to evaluate the effect of different spacing on weed interference, growth and yield of watermelon in Ikorodu agro-ecology during the rainy season of 2019 . Three different spacing namely: $1 \mathrm{~m} \times 1 \mathrm{~m}, 1 \mathrm{~m} \times 0.5 \mathrm{~m}$, and $1 \mathrm{~m} \times$ $1.5 \mathrm{~m}$ replicated three times were used. Data collected included weed fresh weight, weed cover score, weed density, vine length, number of leaves, vine girth at 3,6 and 9 weeks after planting (WAT) and number of fruit, fruit diameter and yield per plot at harvest. Data collected were subjected to one-way analysis of variance (ANOVA) and where significant difference exist, means of treatments were compared using Duncan Multiple Range Test (DMRT) at $5 \%$ level of probability. Results showed that sowing watermelon at $1 \mathrm{~m} \times 0.5 \mathrm{~m}$ produced plants with thicker vines $(4.10 \mathrm{~cm})$ and weed cover score $(4.00)$ compared to sowing at $1 \mathrm{~m} \times 1 \mathrm{~m}(3.86 \mathrm{~cm})$ and $(6.66)$ respectively. Watermelon spaced at $1 \mathrm{~m} \times 1 \mathrm{~m}$ spacing has the highest number of fruit $(6.67)$ and fruit diameter $(11.99 \mathrm{~cm})$ follow by $1 \mathrm{~m} \times 0.5 \mathrm{~m}(4.67)$ and $(10.79 \mathrm{~cm})$ and $1 \mathrm{~m} \times 1.5 \mathrm{~m}$ having the least number of fruit and fruit diameter respectively. For optimum weed suppression which will in turn increase yield of the crop, it is therefore suggested that farmers should adopt $1 \mathrm{~m} \times 0.5 \mathrm{~m}$ spacing in watermelon production. Further study in other humid agro ecological zone is equally recommended.
\end{abstract}

\section{Introduction}

Watermelon (Citrullus lanatus) belongs to the family Cucurbitaceae [1] with its centre of origin traced to both the Kalahari and Sahara deserts in Africa [2]. In Nigeria, watermelon cultivation has considerably increased in the last one decade with the major production areas located in the Sahel, Sudan and Guinea agro-ecological zones. In recent times, its cultivation has stretched down to the forest belts of south western Nigeria [3].

Like many other tropical countries, most cropping systems in Nigeria are traditional and varies across agroecological zones and diverse according to cultural food needs of resource-poor farmers. Watermelon is commonly planted in rows of varying spaces; less effort has been made to plant at optimum densities to maximize its productivity in different agro-ecological zones. Yield variables of crops are influenced by plant competition or by changes in plant population density.

Plant population or plant spacing is a crucial factor for attainment of maximum crop yield which is influenced by inter and intra row crops spacing. Normally, yield per unit area tends to increase as plant density increases up to a point and then declines [4]. Reducing the space between neighbour rows at any particular plant population has several potential advantages. First, it reduces competition among plants within rows for light, water and nutrients due to a more equidistant plant 
arrangement [5]. Secondly, light interception maximization from early canopy closure also decreases transmittance through the canopy, et al. [6]. The smaller amount of sunlight striking the ground decreases the prospective weed interference, especially for shade-intolerant species [7]. Thirdly, the faster shading of soil water being lost by evaporation [8]. This is particularly important under favourable soil surface moisture conditions since it allows crop plants to exploit photosynthesis and the amount of water that is requires for growth processes rather than been evaporated from the soil [9]. Besides, earlier crop cover provided by smaller row width is contributory to enhance soil protection, diminishing water runoff and soil erosion [10]. The nutrient use efficiency can be improved with the use of optimum plant population [11].

The results of many studies have also shown that spacing altered the plant architecture, photosynthetic efficiency of leaves, fruit size and fruit production pattern. According to Heuvelink, et al. [12], both too narrow and too wide spacing do affect crops yield through competition and shading effect. Olson and Sander [5] opined that the major reason for increasing yields in narrow-row systems is the decrease of struggle among crop plants for light, nutrients and water due to an equidistant spatial arrangement of them.

Implementation of plant density strategies and nutrient management has been reported to have a positive impact on watermelon yield by suppressing weed infestation [13]. So it is imperative to develop inter and intra row-spacing recommendation which may help the crop plant to utilize resources more effectively and efficiently towards increased production, productivity and fruit quality [14]. Although watermelon is cultivated almost in all parts of Nigeria, little work has been done on knowing the methods of cultivation and crop raising patterns to get the high plant production in the different agro climatic zones. Therefore, the main objective of the present study was to know the effect of different spacing on weed interference and performance of watermelon (Citrullus lanatus) in the south western Nigeria rain forest.

\section{Materials and methods}

\section{Description of the experimental site}

The experiments were carried out at Teaching and Research Farm, Lagos State Polytechnic, Ikorodu which is geographically lies between Latitude $5^{\circ} 10^{\prime} \mathrm{N}$ and Longitude $3^{\circ} 16^{\prime} \mathrm{E}$ in the humid rainforest agro ecological zone at elevation of 50 meters above sea level. The average minimum and maximum temperature for the aforementioned growing season was $25^{\circ} \mathrm{C}$ and $29^{\circ} \mathrm{C}$ respectively. The annual rainfall ranges between $1670 \mathrm{~mm}$ to $2200 \mathrm{~mm}$, and relative humidity between $65 \%$ and $68 \%$. The experimental plot was cropped with maize over two years without any forms soil amendments and subsequently left to fallow for a year prior to the trial.

\section{Experimental design and treatments}

The experiment was arranged in a randomized complete block design (RCBD) with three levels of spacing: 1m x 1m (15 plants/plot), $1 \mathrm{~m} \times 0.5 \mathrm{~m}$ (30 plants/plot) and $1 \mathrm{~m} \times 1.5 \mathrm{~m}$ (10 plants/plot) and replicated thrice on $234 \mathrm{~m}^{2}$ area of land. The size of each experimental plot was $3 \mathrm{~m} \times 5 \mathrm{~m}^{2}$ accommodating 15,30 and 10 plant/plot for $1 \mathrm{~m} \times 1 \mathrm{~m}, 1 \mathrm{~m} \times 0.5 \mathrm{~m}$ and $1 \mathrm{~m} \times 1.5 \mathrm{~m}$ intra row spacing respectively with a distance of $1 \mathrm{~m}$ between the replicates. Prior to sowing, the experimental plot was ploughed and harrowed to obtained a fine tilth and 8 plots with size of $3 \mathrm{~m} \times 5 \mathrm{~m}$ was measured and laid out. Watermelon seeds (Kaolack cultivar) obtained from Agro-allied store Sabo market, Ikorodu, Lagos was planted on the main field in accordance with different treatments. All agronomic/cultural practices such as thinning, supplying, weeding, pest and diseases control necessary for watermelon cultivation were carried out as when necessary and per the recommendation.

\section{Data collection and statistical analysis}

Five (5) plant stands were randomly sampled and tagged per plot for data collection to determine some growth parameters, while yield characteristics were measured during the harvesting period of the crop. Growth parameters measured include vine length $(\mathrm{cm})$, vine girth $(\mathrm{cm})$ number of leaves/ plant, and number of vegetative branches/plant. At 3, 6 and 9 weeks after planting (WAP) Yield parameters such as number of fruits/plant, fruit diameter $(\mathrm{cm})$, fruit weight $(\mathrm{g})$ and total yield (tons/ha).

Weed density was determined by using a $1 \mathrm{~m}^{2}$ quadrat placed at random in each plot at 3, 6 and 9 weeks after sowing (WAS). Then the number of weeds in the portion were the quadrant was placed in the plot were harvested and counted [15]. Weed cover score was determined at 3, 6, and 9 WAP using visual rating base on $0-9$ scale where 10 represents full weed cover, 3 represented sparse weed coverage; 5 represented intermediate weed coverage; 6 represented high weed coverage; 8 represented severe weed coverage; and 0 represented no weed cover [15]. Fresh weight of weeds was recorded by weighing weeds collected from the treatment plots by uprooting them from the ground and remove the soil from the root part of plant and weigh immediately.

\section{Data analysis}

All data collected were subjected to one-way analysis of variance (ANOVA) following statistical procedures of SAS software program version 9.2 [15] and where treatment effects were significant, the means were separated using the Duncan Multiple Range Test procedures at $5 \%$ probability $(\mathrm{p}<0.05)$ level [17].

\section{Results}

\section{Effect of spacing on vine length and girth of watermelon}

Result shows that vine length of watermelon was not significantly $(\mathrm{p}<0.05)$ affected at 6 and 9 WAP by different spacing adopted (Table 1). However, vine girth was significantly $(\mathrm{p}<0.05)$ affected by spacing at 3WAP compared to the nonsignificant $(\mathrm{p}<0.05)$ difference observed at 6 , and 9 WAP (Table 1). Though, longest vine was recorded from watermelon spaced at $1 \mathrm{~m} \times 1.5 \mathrm{~m}$ at $3 \mathrm{WAP}(26.09 \mathrm{~cm})$ and least length recorded from $1 \mathrm{~m} \times 1 \mathrm{~m}$ spacing $(24.42 \mathrm{~cm})$, similar trend was recorded at 
9WAP. Highest vine girth was observed in watermelon spaced $1 \mathrm{~m} \times 1.5 \mathrm{~m}$ at 3 WAP $(4.53 \mathrm{~cm})$ and 9 WAP (10.57) respectively (Table 1).

\section{Effect of spacing on number of leaves and branches of watermelon}

Table 2 shows that number of leaves and branches of watermelon were not significantly $(\mathrm{p}<0.05)$ affected at 3 , 6 , and 9 WAP. The result obtained express that number of leaves increases progressively even at reproductive stage as watermelon planted at $1 \mathrm{~m} \times 1 \mathrm{~m}$ recorded the highest (73.23) follow by $1 \mathrm{~m} \times 0.5 \mathrm{~m}$ (71.53) and $1 \mathrm{~m} \times 1.5 \mathrm{~m}$ spacing having the least (65.73). The result also shows that large-spaced plot has the lowest number of branches (Table 2). At 3 WAP, watermelon spaced at $1 \mathrm{~m} \times 0.5 \mathrm{~m}$ has the highest number of branches (2.8) follow by $1 \mathrm{~m} \times 1 \mathrm{~m}$ (2.67) then $1 \mathrm{~m} \times 1.5 \mathrm{~m}$ having the least (2.6). While at 6 and 9 WAP, $1 \mathrm{~m} \times 1.5 \mathrm{~m}$ has the highest number of branches (3.4) and (4.2) follow by $1 \mathrm{~m} \times 0.5 \mathrm{~m}$ (4.07) and $1 \mathrm{~m} \mathrm{x}$ $1 \mathrm{~m}$ (3.87) respectively.

\section{Effect of spacing on weed competition}

Table 3 shows that weed cover score and weed density was significantly affected by different spacing at 3 and 9WAP respectively. While weed fresh weight was significantly $(\mathrm{p}<0.05)$ different at 3 WAP. Watermelon planted with $1 \mathrm{~m} \times 1 \mathrm{~m}$ spacing has the highest weed cover score (6.67) at 9WAP follow by $1 \mathrm{~m} \times 1.5 \mathrm{~m}$ (5.0) then $1 \mathrm{~m} 0.5 \mathrm{~m}$ (4.0) having the least. Highest weed density was recorded in watermelon spaced at $1 \mathrm{~m} \times 1 \mathrm{~m}$ (20.33) follow by $1 \mathrm{~m} \times 0.5 \mathrm{~m}$ (10.67) and $1 \mathrm{~m} \times 1.5 \mathrm{~m}$ (7.67) at $6 \mathrm{WAP}$. At 9WAP, $1 \mathrm{~m} \times 1.5 \mathrm{~m}$ recorded the higher weed density

Table 1: Effect of spacing on vine length and girth of watermelon

\begin{tabular}{|c|c|c|c|c|c|c|}
\hline & \multicolumn{3}{|c|}{ Vine length weeks (cm) } & \multicolumn{4}{c|}{ Vine girth (cm) } \\
\hline Treatments & 3 WAP & 6 WAP & 9 WAP & 3 WAP & 6 WAP & 9 WAP \\
\hline $1 \mathrm{~m} \times 1 \mathrm{~m}$ & 24.42 & 94.60 & 108.84 & $3.86 \mathrm{~b}$ & 7.22 & 9.87 \\
\hline $1 \mathrm{~m} \times 0.5 \mathrm{~m}$ & 25.17 & 87.63 & 135.37 & $4.10 \mathrm{a}$ & 7.033 & 9.74 \\
\hline $1 \mathrm{~m} \times 1.5 \mathrm{~m}$ & 26.09 & 86.79 & 126.37 & $4.53 \mathrm{ab}$ & 5.90 & 10.57 \\
\hline F-Test & $\mathrm{ns}$ & $\mathrm{ns}$ & $\mathrm{ns}$ & $\star$ & $\mathrm{ns}$ & $\mathrm{ns}$ \\
\hline SE & 1.27 & 5.56 & 10.44 & 0.15 & 0.15 & 0.15 \\
\hline
\end{tabular}

* - significant at 5\%; ns- not significant; WAP: Weeks After Planting

Each value is the mean \pm standard error of the three replicates. Values in the same column with same letter(s) do not differ significantly at $p>0.005$ using Turkey's honest significance test

Table 2: Effect of spacing on number of leaves and branches of watermelon.

\begin{tabular}{|c|c|c|c|c|c|c|}
\hline & \multicolumn{3}{|c|}{$\begin{array}{c}\text { Number of leaves } \\
\text { Weeks after planting }\end{array}$} & \multicolumn{3}{c|}{$\begin{array}{c}\text { Number of branches } \\
\text { Weeks after planting }\end{array}$} \\
\hline Treatments & 3 & 6 & 9 & 3 & 6 & 9 \\
\hline $1 \mathrm{~m} \times 1 \mathrm{~m}$ & 9.60 & 30.00 & 73.23 & 2.67 & 3.33 & 3.87 \\
\hline $1 \mathrm{~m} \times 0.5 \mathrm{~m}$ & 8.27 & 52.40 & 71.53 & 2.80 & 3.27 & 4.07 \\
\hline $1 \mathrm{~m} \times 1.5 \mathrm{~m}$ & 8.33 & 31.33 & 65.73 & 2.60 & 3.40 & 4.20 \\
\hline F-Test & $\mathrm{ns}$ & $\mathrm{ns}$ & $\mathrm{ns}$ & $\mathrm{ns}$ & $\mathrm{ns}$ & $\mathrm{ns}$ \\
\hline SE & 1.10 & 8.06 & 3.37 & 0.08 & 0.17 & 4.20 \\
\hline
\end{tabular}

Each value is the mean \pm standard error of the three replicates. Values in the same column with same letter(s) do not differ significantly at $p>0.005$ using Turkey's honest significance test
Table 3: Effect of spacing on vine length and girth of watermelon.

\begin{tabular}{|c|c|c|c|c|c|c|c|c|}
\hline & \multicolumn{3}{|c|}{ Weed cover score } & \multicolumn{3}{|c|}{ Weed fresh weight (g) } & \multicolumn{2}{|c|}{ weed density } \\
\hline Treatments & 3 WAP & 6 WAP & 9 9WAP & 3WAP & 6 WAP & $\begin{array}{r}\text { 9WAP } \\
\text { 3WAP }\end{array}$ & 6 WAP & 9 WAP \\
\hline $1 \mathrm{~m} \times 1 \mathrm{~m}$ & $5.67 \mathrm{a}$ & 5.67 & $6.66 \mathrm{a}$ & $42.67 \mathrm{a}$ & 34.00 & 16.33 & $\begin{array}{c}20.33 \mathrm{a} \\
15.33\end{array}$ & $4.67 \mathrm{~b}$ \\
\hline $1 \mathrm{~m} \times 0.5 \mathrm{~m}$ & $6.33 \mathrm{a}$ & 5.33 & $4.00 \mathrm{~b}$ & $16.67 \mathrm{~b}$ & 21.3 & $\begin{array}{r}19.67 \\
10.67 \mathrm{ab}\end{array}$ & 13.00 & $6.67 \mathrm{~b}$ \\
\hline $1 \mathrm{~m} \times 1.5 \mathrm{~m}$ & $3.67 \mathrm{~b}$ & 5.67 & $5.00 \mathrm{ab}$ & $7.33 \mathrm{~b}$ & 34.67 & $\begin{array}{r}32.00 \\
7.67 b\end{array}$ & 12.00 & $13.33 \mathrm{a}$ \\
\hline $\mathrm{F}-\mathrm{Test}$ & $*$ & $\mathrm{~ns}$ & $*$ & $*$ & $\mathrm{Ns}$ & $\mathrm{Ns} *$ & $\mathrm{Ns}$ & $*$ \\
\hline SE & 0.19 & 0.81 & 0.35 & 6.14 & 9.57 & 7.343 .22 & 2.63 & 1.58 \\
\hline
\end{tabular}

* - significant at 5\%; ns - not significant, WAP - Weeks After Planting, SE: Standard Error

Each value is the mean \pm standard error of the three replicates. Values in the same column with same letter(s) do not differ significantly at $p>0.005$ using Turkey's

honest significance test

follow by $1 \mathrm{~m} \times 0.5 \mathrm{~m}$ and $1 \mathrm{~m} \times 1 \mathrm{~m}$. From the result in Table 3 , highest weed fresh weight $(32,0 \mathrm{~g})$ was obtained from $1 \mathrm{~m} \mathrm{x}$ $1.5 \mathrm{~m}$ plot followed by $1 \mathrm{~m} \times 0.5 \mathrm{~m}(19.67 \mathrm{~g})$ and then $1 \mathrm{~m} \times 1 \mathrm{~m}$ having the least but comparable with $1 \mathrm{~m} \times 0.5 \mathrm{~m}$.

\section{Effect of spacing on yield attributes of watermelon}

Figures 1 shows that yield attributes of watermelon (number of fruits, fruit diameter and fruit weight) were not significantly $(\mathrm{p}<0.05)$ affected by the different spacing evaluated in the present study. However, watermelon planted with $1 \mathrm{~m} \mathrm{x}$ $1 \mathrm{~m}$ spacing has the highest number of fruit (6.67) and fruit diameter $(11.99 \mathrm{~cm})$ follow by $1 \mathrm{~m} \times 0.5 \mathrm{~m}$ spacing $(4.67)$ and $(10.79 \mathrm{~cm})$ and $1 \mathrm{~m} \times 1.5 \mathrm{~m}$ spacing having the least number of fruit and fruit diameter respectively. While, highest fruit yield per hectare was obtained from watermelon in $1 \mathrm{~m} \mathrm{x} 0.5 \mathrm{~m}$ plots follow by those in $1 \mathrm{~m} \mathrm{x} 1 \mathrm{~m}$ and $1 \mathrm{~m} \times 1.5 \mathrm{~m}$ having the least.

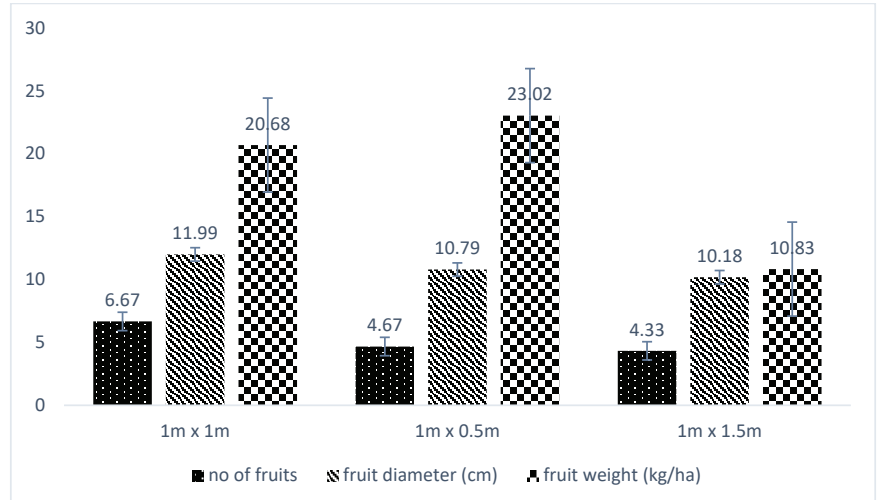

Figure 1: Effect of spacing on yield attributes of watermelon.

\section{Discussion}

Manipulation of plant populations, through row spacing is a critical agricultural factor and management tool that can be used to modify crop productivity has great effect on crop growth and the yield components of individual plants [18]. Plant spacing correctly identified has a great effect on growth, development, seed yield and yield components.

Citation: Adenubi 0O, Sanni KO (2020) Effect of different spacing on weed interference and performance of watermelon (Citrullus Lanatus) in South Western Nigeria Rainforest Zone. Int J Agric Sc Food Technol 6(2): 166-170. DOI: https://dx.doi.org/10.17352/2455-815X.000068 
Wider spacing in the study give rise to higher weed infestation on the plots. The implication of the result obtained is that choosing narrow spacing in watermelon increases plant population thereby lower weed density than planting at wider spacing [19]. This finding is in consonant with the that of Dalley, et al. [20] who detected that narrowing spacing increases light interception by the crop particularly in the early growing season, thereby leading to increased crop growth rates and earlier canopy closure thereby suppressed weed growth. This study also aligned with the findings of Adigun [21] who observed that spacing of $30 \mathrm{~cm}$ resulted in significantly lower weed cover score than those of $45 \mathrm{~cm}$ intra row spacing in tomato. Various study had shown that increase in plant density reduces the likelihood of the effect of weed struggle with crops and improved light interception with crops; thus leading to improved crop growth and earlier canopy closure which accordingly increase in crop yield [22,23]. Wider spacing recorded significant highest weed fresh weight compared to closed spacing. Evidently, crop canopy closure developed much earlier in plots with closer spacing of $1 \mathrm{~m} \mathrm{x} 0.5 \mathrm{~m}$ resulting in shade that reduced weed density and dry matter. Street, et al. [24] reported reduced dry matter production with increased cotton density.

The highest vine girth was recorded from the highest inter and intra row spacing and the lowest girth from the lowest intra row spacing respectively. The girth of watermelon increases progressively with the age of plant. These confirm that largespaced plot has appreciable effect on vine girth development. The result shows that with an increase in spacing, that the wider area planted crops can exploit more nutrients and moisture for growth and development that results for vine growth. This finding is in agreement with the report of Ossom, et al. [25] who reported that larger spacing in watermelon indices increases vine girth growth. Similarly, Dean, et al. [26] also observed that in-row plant spacing has a significant effect on the growth and yield of watermelon. In another study, and Enujeke [27] reported that maize plants sown at a spacing of $35 \mathrm{~cm}$ were superior in stem girth over those sown at narrower or smaller spacing possibly because the plants obtained more soil moisture and nutrients than narrower-spaced plants. While, Dalley, et al. and Azam [28], reported that wider-spaced maize plants obtained more soil moisture and nutrients than narrower plants.

It was understood that vine length increases as age increases in this study and that watermelon spaced at $1 \mathrm{~m} \mathrm{x}$ $0.5 \mathrm{~m}$ have the longest vine length, which is in agreement with the findings of Efediyi, et al. [29] who reported that the spacing has positive effect on plant height. These results also support the work done by Dean, et al. [26] who observed that in-row plant spacing has a significant effect on the growth and yield of water melon. However, these results are not in agreement with Sabo, et al. [13] who reported an increase in watermelon vine length with an increase in spacing.

Smith and Hamel [30] indicated that branching is important characteristics by which plants may adapt their size to the availability of resources. Result obtained from this study shows spacing did not significantly affect the number of branches produced but show that large-spaced plot has the lowest number of branches. This report negates Cushman, et al. [31] who reported that larger spacing improves number of branches in watermelon. The result is also against the submission of Dean, et al. [26], Mangala and Mausia [32], who found out that number of branches increases as spacing increases.

The result obtained express that number of leaves of watermelon increases progressively even at reproductive stage as watermelon planted at $1 \mathrm{~m} \times 1 \mathrm{~m}$ spacing recorded the highest number of leaves (73.23). These results get support from the work done by Sabo, et al. [13] who reported that there is no significant difference in all the level of spacing used in promoting number of leaves of watermelon.

Highest fruit yield per hectare was recorded on watermelon spaced at $1 \mathrm{~m} \times 0.5 \mathrm{~m}$. This result seems to be in contrary with some theories as it is believed that large-spaced plot should have the highest fruit yield per hectare due to less plant population coupled with large feeding area. The low yield could be due to weed infestation on large-spaced plot. Wider spacing of a cover crop does not suppress weed growth; it enhances weed growth instead due to large space on the plot. On this note, weed infestation could reduce the yield of the largespaced plot (1m x 1.5m). The highest yield recorded from small spaced could be due to increase in plant population. This result was confirmed by several studies [2, 33-36], who noticed that decrease in plant population due to wider planting distance, increased shoot fresh mass which is a known vegetative component of watermelon, vine lengths and number of leaves as well as number of fruits and fruit yield of watermelons were significantly affected by the planting spacing. This result is supported by Motsenbocker and Arancibia [34], who reported that wider spacing decrease number of plant per area and decrease fruit number per plant and yield of watermelon.

\section{Conclusion}

Different levels of spacing significantly affected the growth and yield of watermelon as shown in the results obtained from this study. Watermelon spaced at $1 \mathrm{~m} \times 0.5 \mathrm{~m}$ provided the best weed suppression and high fruits yield. Hence, for optimum weed suppression which will in turn increases yield of the crop, it is suggested that farmers in the study area should adopt $1 \mathrm{~m} \times 0.5 \mathrm{~m}$ spacing in Citrullus lanatus production. Also it is recommended that further study be conducted in other humid agro ecological zone of Nigeria in other to explore the possibilities of having uniform spacing for the cultivation of water melon.

\section{References}

1. Schippers RR (2000) African Indigenous Vegetables. An Overview of the Cultivated Species. Natural Resources Institute/ACP-EU Technical Centre for Agricultural and Rural Cooperation, Chatham 214. Link: https://bit.ly/2F73tLy

2. Mayberry KS, Hartz TK, Valenzia J (2008) Watermelon Production in California Vegetable Research and Information Center. University of California. Link: https://bit.ly/357iOq9

3. NIHORT (2000) National Horticultural Research Institute. 25 years of 
research into Horticultural Crops Development in Nigeria (1975 - 2000). A Commemorative Publication 120-122. Link: https://bit.ly/3bsmoMV

4. Akintoye HA, Kintomo AA, Adekunle AA (2009) Yield and fruit quality of watermelon in response to plant population. International Journal of Vegetable Science 15: 369- 380. Link: https://bit.ly/2Zbx9y9

5. Olson RA, Sander DJ (1988) Corn production. In: Sprague, G. F., Dudley, J. W. Corn and corn production. Madison: ASA CSSA \& SSSA Press 639-686. Link: https://bit.ly/32Zm58j

6. McLachlan SM, Swanton CJ, Weise SF, Tollenaar M (1993) Effect of corninduced shading and temperature on rate of leaf appearance in redroot pigweed (Amaranthus retroflexus L.). Weed Sci 41: 590-593. Link: https://bit.ly/2F02rkK

7. Gunsolus JL (1990) Mechanical and cultural weed control in corn and soybeans. Am J Altern Agric Greenbelt 5: 114-119. Link: https://bit.ly/2QWAwED

8. Karlen DL, Camp CR (1985) Row Spacing, Plant Population, and Wate Management Effects on Corn in the Atlantic Coastal Plain. Agronomy Journal 77: 393-398. Link: https://bit.ly/321pPao

9. Lauer J, McDonald MJ, Sullivan MB (1994) The pathway of water uptake in maize seeds. The Ohio State Univ., Columbus (USA). Department of Agronomy). Link: https://bit.ly/334f9Xw

10. Sangoi L, Salvador RJ (1998) Maize susceptibility to drought at flowering a new approach to overcome the problem. Ciência Rural 28: 699-706. Link: https://bit.ly/3jO0Ahz

11. Muhidin B (2019) Effect of Inter-and Intra-Row Spacing on Yield and Yield Components of Maize QPM Hybrid, BHQPY545 in South western Ethiopia. International Journal of Research Studies in Science, Engineering and Technology 6: 19-26. Link: https://bit.ly/3IPKfL7

12. Heuvelink E, Marcelis LFM, Bakker MJ, Vanderploeg A (2009) The use of Crop Models to Evaluate Physiological Traits in Genotypes of Horticulture Crops. Horticultural Production Chains Group, Wageningen University. Oxfordshire OX10 8DE, UK. Link: https://bit.ly/322a2YJ

13. Sabo MU, Wailare MA, Aliyu M, Jari S, Shuaibu YM (2013) The effect of NPK fertilizer and spacing levels on growth and yield of Watermelon (Citrillus lanatus L). Scholarly Journal of Agricultural Science 3: 325- 330. Link: https://bit.ly/31Y5en4

14. Ara N, Bashar MK, Kakon SS (2007) Effect of Spacing and Stem Pruning on the Growth and Yield of Tomato. Int J Sustain Crop Prod 2: 35-39. Link: https://bit.ly/2QYzyrm

15. Adigun JA, Adeyemi OR, Lagoke STO, Olorunmaiye PM, Daramola OS, et al. (2016) Influence of inter-row spacing and weed Control methods in groundnut (Arachis hypogeal (L.). Journal of Agricultural Science and Environment 16 86-95. Link: https://bit.ly/357YDIX

16. SAS (Statistical Analysis System) Institute (2004) SAS user guides, version 9.1.SAS Inc. Cary. North Carolina, USA

17. Gomez KA, Gomez AA (1984) Statistical procedures for agricultural research, 2nd edition. John Wiley and Sons Inc., New York. Link: https://bit.ly/3jPwBGc

18. Diepenbrock W (2000) Yield analysis of winter oilseed rape (Brassica napus L.): a review. Field Crops Research 67: 35-49. Link: https://bit.ly/2Dv2G6v

19. Reiners S, Riggs DIM (2007) Plant Spacing and Variety Affect water melon
Yield and Fruit Size, but Supplemental Nitrogen Does Not. Horticulture Science 32: 1037-1039.

20. Dalley CD, Kells JJ, Renner KA (2004) Effect of glyphosate application timing and row spacing on weed growth in corn (Zea mays L.) and soyabean (Glycine max). Weed Technology 18: 177-182. Link: https://bit.ly/2QZ0d7r

21. Adigun JA (2001) Influence of intra -row spacing and chemical weed contro on growth and yield of chilli pepper in the Nigerian Northern Guinea Savannah. Nigerian Journal of Horticultural Science 5: 67-73.

22. Osipitan OA, Adigun JA, Lagoke STO, Afolami SO (2013) Effect of interrow spacing and weed control methods on growth and yield of cowpea (Vigna unguiculata L. Walp) in South Western Nigeria. Nigerian Journal Plant Protection 27: 97-111. Link: https://bit.ly/3bszEB4

23. Adigun JA, Osipitan OA, Lagoke STO, Adeyemi OR, et al. (2014) Growth and Yield Performance of Cowpea (Vigna Unguiculata (L.) Walp) as influenced by Row-Spacing and Period of Weed interference in South-West Nigeria 6: 188 198. Link: https://bit.ly/3jPa8ZE

24. Street JE, Buchanan G, Crowley A, Mcguive RH (1981) Influence of cotton (Gossypium hirsutum) densities on competitiveness of pig weed (Amaranthus spp and sicle pod (Cassia obtusifolia). Weed Science 29: 253-256. Link: https://bit.ly/3IVeGzu

25. Ossom DTT, Minimah OSO, Edet Rhykerd CL (2001) Influence of spacing on yield, weed infestation and mineral concentration of the watermelon, Indiana Academy of Science 99: 191-198.

26. Dean B, Smiljana GB, Milan O, Josipa H, Bruno N, et al. (2011) Growth and Yield Response of Watermelon to in row Plant Spacings and Mycorrhiza. Chilean Journal Agricultural Research 71. Link: https://bit.ly/2Z8qIMi

27. Enujeke EC (2013) Effects of Variety and Spacing on Growth Characters of Hybrid Maize. Asian Journal of Agriculture and Rural Development 3: 296-310.

28. Azam S, Ali M, Amin M, Bibi S, Arif M (2007) Effect of plant population on maize hybrids. Journal of Agricultural and Biological Science 2: 104-111. Link: https://bit.ly/3jSKUK9

29. Efediyi EK, Samson UR (2009) Effect of inorganic fertilizer on the yield of two varieties of cucumber (Cucumis sativum L.), Report and Opinion 5: 74-79.

30. Smith L, Hamel C (1999) Crop yield: Physiology and processes. Springerverlag, Berlin Heidelberg, Germany. Link: https://bit.ly/2QXQILe

31. Cushman KE, Nagel DH, Horgan TE, Gerrard PD (2004) Plant population affects watermelon yield components. Horticultural Technology 14

32. Mangala R, Mausia S (2006) Hand book of Agriculture. 169.

33. Dantata (2014) Assessing Watermelon Cultivars under Different Planting Distances in Bauchi North, Nigeria. Asian Journal of Applied Science 2: 381 386. Link: https://bit.ly/320LGyH

34. Motsenbocker CE, Arancibia RA (2002) In-row spacing influences triploid watermelon yield and crop value. Horticultural Technology Journal 12: 437440. Link: https://bit.ly/3bsA8am

35. Diepenbrock W (2000) Yield analysis of winter oilseed rape (Brassica napus L.): a review. Field Crops Research 67: 35-49. Link: https://bit.ly/357k0tD

36. Johnson BL, Hanson BK (2003) Row-Spacing interactions on spring canola performance in the northern great plains. Agronomy Journal 95: 703-708. Link: https://bit.ly/3h3DrWJ

Copyright: ( 2020 Adenubi 00, et al. This is an open-access article distributed under the terms of the Creative Commons Attribution License, which permits unrestricted use, distribution, and reproduction in any medium, provided the original author and source are credited.

Citation: Adenubi OO, Sanni KO (2020) Effect of different spacing on weed interference and performance of watermelon (Citrullus Lanatus) in South Western Nigeria Rainforest Zone. Int J Agric Sc Food Technol 6(2): 166-170. DOI: https://dx.doi.org/10.17352/2455-815X.000068 